\title{
PREVALENCE AND CHARACTERISTIC MULTIDRUG RESISTANT ORGANISMS IN INTENSIVE CARE UNIT OF Dr. WAHIDIN SUDIROHUSODO HOSPITAL MAKASSAR
}

\author{
Sitti Khadijah, Irda Handayani, Nurhayana Sennang \\ Department of Clinical Pathology, Faculty of Medicine, Hasanuddin University/Dr. Wahidin Sudirohusodo Hospital, Makassar, Indonesia. \\ E-mail: idjonksittikhadijah@gmail.com
}

\begin{abstract}
Multidrug-Resistant Organisms (MDROs) are microorganisms, common bacteria, which are resistant to one or more classes of antimicrobial agents. The spread of these organisms can emerge new types of infection that are difficult to treat, and cause increase medical cost, prolong patient's length of stay and increase mortality rates. This study aimed to know the prevalence and characteristic of MDRO in the intensive care unit to get better management of infection. This study was a retrospective description, including the results of all MDRO antibiotic sensitivity tests in ICU, PICU, and NICU at the Dr. Wahidin Sudirohusodo Hospital in Makassar. The sensitivity tests were isolated and identified using VITEK 2 from January to December 2016. Total samples were 136 samples, consisting of four species of bacteria namely Klebsiella pneumoniae 12 (8.8\%), Acinetobacter baumannii 26 (19.1\%), Burkholderia cepacia 93 (68.4\%), and Escherichia coli 5 (3.7\%). The multidrug-resistant organism was found mostly in postoperative patients: in NICU 10 (43.5\%), in PICU 18 (45.0\%), and in ICU 45 (61.6\%). MDRO was also identified among patients using three or more health devices: 13 in NICU (56.5\%), 18 in PICU (45.0\%), and 56 in ICU (76.7\%). MDRO was mostly found among patients who were resistant to more than three antibiotic classes. The average length of stay in NICU, PICU, and ICU were 23 days, 20 days, and 27 days respectively. It was also reported that the patients with MDRO who died were more than those who improved after hospitalization. Patients in intensive care were particularly susceptible to infections due to immunocompromised conditions and invasive medical procedures. The researchers recommend the identification of MDRO infection risk, and the through use of antibiotics treatment.
\end{abstract}

Key word: Multidrug-resistant organisms, intensive care unit, characteristic

\section{INTRODUCTION}

Antibiotic is antibacterial substance produced by microorganisms which, is suppress other organisms growth. First antibiotic (penicillin) was found in 1928 by Alexander Fleming, who was a microbiologist from England. In 1930, penicillin began to used by the infected patient. However, there was a resistant to penicillin called penicillinase. ${ }^{1}$

Antibiotic-resistant is an increase in bacteria ability to resist the antibiotic which is given. This cause bacteria does not respond to the antibiotic. When this organism spread in the community will threaten people and emerge a new infection, which is more difficult to cure and increase the cost of treatment. It will prolong the patient's length of stay, and increase mortality rates. ${ }^{2,3}$

Multidrug-resistant organisms are micro-organisms, most of it is bacteria, resistant to one or more classes of antibiotic. In spite of, the term of certain MDRO describes to resistant of one agent.
For example, methicillin-resistant Staphylococcus aureus (MRSA), vancomycin resistant Enterococcus (VRE), vancomycin-resistant Staphylococcus aureus (VRSA) dan Multidrug-resistant Acinetobacter baumannii (MDRAB). These pathogens are resistant to antimicrobe agent often used. These high resistant organisms are necessary to be more noticed in healthcare facilities. Except for MRSA and VRE, there is another kind of MDRO such as Enterobacteriaceae producing Extended-Spectrum Beta-Lactamase (ESBL) and Klebsiella pneumoniae Carbapenemase producer (KPC). Multidrug-resistant organisms implicate significant to infection management which is not found yet whether only limited handle based on prior manual isolation. $^{4-6}$

Statistical data showed that the prevalence of MDRO in Indonesia increases every year. Prevalence of MRSA in 1986 is $2.5 \%$ and increased to $23.5 \%$ in 2006. Prevalence of Enterobacteriaceae producing ESBL in the Harapan Kita Hospital gain 16\% which main caused in the Pediatric Intensive Care Unit 
(PICU) is Klebsiella pneumoniae (14\%) and second most agent caused is E.coli (19\%). There was a research study in 2010 about Staphylococcus aureus sensitivity to vancomycin in Margono Soekarjo Purwokerto Hospital, Central Java, and it was found VRSA in 10 from 60 samples (15.6\%) from stethoscope. In the United States by the year 2000, it was $25.9 \%$ Enterococcus isolated by blood samples proved that resistant to vancomycin. ${ }^{6,7}$

Hospital care facilities very vary by physical and functional characteristics of the intensive care unit, burn injury unit, Neonatal Intensive Care Unit (NICU). A patient may be infected to MDRO. A patient who had been infected may contaminate the infection to others sick or healthy people. The medical officer may be one of element risk spreading infection when they ignore the rules of infection precaution and five moments handwash. Five moments consist of before contact with the patient, before doing a patient, after doing a patient, after contact with the patient, and after contact to patient's neighbourhood. ${ }^{8}$

This study purposed to understand about prevalence and characteristics of Multidrug-Resistant Organism (MDRO) in the intensive care unit of Wahidin Sudirohusodo Makassar Hospital.

Ethical clearance in this study was obtained from the Commission for Research Ethics at the Dr. Wahidin Sudirohusodo Hospital, Makassar with: protocol number: Uh17080564.

\section{METHODS}

This was a retrospective descriptive study; samples were from the Clinical Pathology Laboratory of tropical infection subdivision and electronic medical record of Wahidin Sudirohusodo Makassar Hospital. The sample was all results of antibiotic sensitivity test that MDRO from ICU, PICU, NICU, which was isolated and identified by VITEK 2 during January-December 2016.

All data from the Clinical Pathology Laboratory of tropical infection subdivision were patient identity, ward, the result of antibiotic sensitivity test. Other data were diagnosis, how long of hospital care, history of antibiotic treatment until before antibiotic sensitivity test was taken, utilizing hospital care device, for example, an intravenous catheter, urine catheter, ventilator, central venous catheter, and outgoing hospital record was taken from the electronic medical record. Data were analyzed by SPSS $22^{\text {nd }}$ version, and the result would show on the table.

\section{RESULT AND DISCUSSION}

During January-December 2016, there were 136 samples of antibiotic sensitivity results test with Multidrug-Resistant Organisms (MDRO) in patients of NICU, PICU, and ICU, which were consist of four species. They were Klebsiella pneumoniae (8.8\%), Acinetobacter baumannii (19.1\%), Burkholderia cepacia (68.4\%), and Escherichia coli (3.7\%)

From the results of antibiotic sensitivity test with MDRO, there were 136 samples in ICU was 73 (53.7\%). Most bacteria found was Burkholderia cepacia with amount 93 (68.4\%) (Table 1).

Postoperative patients were found to be the most antibiotic resistant to one or more classes of antibiotics. From all intensive care settings, in NICU was 10 (43.5\%), in PICU was 18 (45.0\%), and in ICU was 45 (61.6\%). Based on the use of medical devices, patients who use 3 or more devices were the highest in all intensive care, in NICU was 13 (56.5\%), in PICU was 18 (45.0\%), and in ICU was 56 (76.7\%) (Table 2).

Patients were given one type of antibiotic were found to be the most results which resistant to one or

Table 1. Characteristic of MDRO in NICU, PICU, ICU

\begin{tabular}{lcccc}
\hline & NICU(\%) & PICU(\%) & ICU(\%) & Total (\%) \\
\hline Staphylococcus aureus & 0 & 0 & 0 & 0 \\
Klebsiella pneumonia & $9(6.6 \%)$ & $1(0.7 \%)$ & $2(1.5)$ & $12(8.8 \%)$ \\
Enterococcus & 0 & 0 & 0 & 0 \\
Acinetobacter baumannii & $4(2.9 \%)$ & $5(3.7 \%)$ & $17(12.5 \%)$ & $26(19.1 \%)$ \\
Bulkholderia cepacia & $10(7.4 \%)$ & $32(23.5 \%)$ & $51(37.5 \%)$ & $\mathbf{9 3}(\mathbf{6 8 . 4 \% )}$ \\
Escherichia coli & 0 & $2(1.5 \%)$ & $3(2.2 \%)$ & $5(3.7 \%)$ \\
\hline
\end{tabular}


Table 2. Sample characteristic in NICU, PICU, ICU

\begin{tabular}{|c|c|c|c|}
\hline Variable & NICU & PICU & ICU \\
\hline \multicolumn{4}{|l|}{ Sex } \\
\hline Male & 17 (73.9\%) & $23(57.5 \%)$ & 47 (64.4\%) \\
\hline Female & $6(26.1 \%)$ & $17(42.5 \%)$ & 26 (35.6\%) \\
\hline \multicolumn{4}{|l|}{ Age } \\
\hline $0-1$ month & 22 (95.7\%) & 0 & 0 \\
\hline 1 month -18 year old & 1 (4.3\%) & 39 (97.5\%) & $3(4.1 \%)$ \\
\hline$>18$ year old & 0 & $1(2.5 \%)$ & 70 (95.9\%) \\
\hline \multicolumn{4}{|l|}{ Diagnose } \\
\hline D/post-op & $10(43.5 \%)$ & $18(45.0 \%)$ & 45 (61.6\%) \\
\hline D/Others & 7 (30.4\%) & $12(30.0 \%)$ & 24 (32.9\%) \\
\hline D/Septic & $6(26.1 \%)$ & $10(25.0 \%)$ & $4(5.5 \%)$ \\
\hline \multicolumn{4}{|l|}{ Medical equipment } \\
\hline 1 equipment & $2(8.7 \%)$ & $6(15.0 \%)$ & $4(5.5 \%)$ \\
\hline 2 equipments & $8(34.8 \%)$ & $16(40.0 \%)$ & $13(17.8 \%)$ \\
\hline$>=3$ equipments & $13(56.5 \%)$ & $18(45.0 \%)$ & 56 (76.7\%) \\
\hline \multicolumn{4}{|l|}{ Antibiotic used } \\
\hline None & $13(56.5 \%)$ & 0 & 5 (6.8\%) \\
\hline 1 antibiotic & $6(26.1 \%)$ & 29 (72.5\%) & 36 (49.3\%) \\
\hline$>=2$ antibiotics & 4 (17.4\%) & $11(27.5 \%)$ & $32(43.8 \%)$ \\
\hline \multicolumn{4}{|l|}{ Antibiotic resistance } \\
\hline$>=2$ groups & 7 (5.1\%) & 14 (10.3\%) & 27 (19.9) \\
\hline$>3$ groups & $12(8.8 \%)$ & $21(15.4 \%)$ & 31 (22.8\%) \\
\hline All groups & $4(2.9 \%)$ & 5 (3.7\%) & 15 (11.0\%) \\
\hline Average length of stay (days) & 23 & 20 & 27 \\
\hline \multicolumn{4}{|l|}{ Outcome } \\
\hline improved & $9(39.1 \%)$ & $18(45.0 \%)$ & $32(43.8 \%)$ \\
\hline died & $14(60.9 \%)$ & $22(55.0 \%)$ & $41(56.2 \%)$ \\
\hline
\end{tabular}

more classes of antibiotics in PICU and ICU, in PICU 29 (72.5\%) and ICU 36 (49.3\%). Patients who had not received antibiotic therapy, had the most antibiotic resistancy to one or more classes of antibiotics in NICU 13 (56.5\%). Based on the level of resistance to antibiotics obtained, most were resistant to more than three classes of antibiotics. The most resistant types of antibiotics were the penicillin, beta-lactam, and aminoglycoside groups (Table 3 ). The average length of stay in each room was NICU for 23 days, PICU for 20 days, and ICU for 27 days. Based on the outgoing patient's situation, it was found that more patients died than those expressed improved after treatment (Table 2).

Klebsiella pneumonia bacteria were most resistant to ampicillin antibiotics at 12 (9.7\%). Acinetobacter baumannii bacteria were most resistant to 26 (7.6\%) amoxicillin antibiotics. Escherichia coli bacteria were most resistant to ampicillin antibiotics by $5(16.1 \%)$ and cefoxitin 5 (16.1\%), and Burkholderia cepacia bacteria most resistant to imipenem antibiotics of 93 (19.2\%) (Table 3).

The results of this study indicate that the highest incidence of MDRO in the intensive care room of the Dr. Wahidin Sudirohusodo Hospital Makassar was found in ICU of 73 (53.7\%) and the most widely isolates found was Burkholderia cepacia species of 51 (37.5\%) (Table 1). Bacterial resistance rates were generally higher in the ICUs than in other service areas in hospitals. ${ }^{9}$ Previous research at a hospital in Surabaya showed the unit with the highest incidence of MDRO was ICU. ${ }^{10}$

The results of this study showed that the group of 
Table 3. Characteristics of bacterial resistance to antibiotics

\begin{tabular}{|c|c|c|c|c|c|}
\hline & K.pneumonia & A.baumannii & E.coli & B.cepacia & Total \\
\hline \multicolumn{6}{|l|}{ Penicillin group } \\
\hline Ampicillin & $12(9.7 \%)$ & 24 (7.0\%) & 5 (16.1\%) & 75 (15.5\%) & 106 \\
\hline Amoxicillin-Clavulanic acid & $6(4.8 \%)$ & $26(7.6 \%)$ & $4(12.9 \%)$ & 85 (17.5\%) & 121 \\
\hline \multicolumn{5}{|l|}{ Beta-lactamase group } & 24 \\
\hline Cefoxitin & $11(8.9 \%)$ & $24(7.0 \%)$ & 5 (16.1\%) & $13(2.7 \%)$ & 53 \\
\hline Cefotaxim e & 5 (4.0\%) & 18 (5.2\%) & $3(9.6 \%)$ & $10(2.0 \%)$ & 36 \\
\hline Ceftazidime & 11 (8.9\%) & 19 (5.5\%) & $3(9.6 \%)$ & 7 (1.4\%) & 40 \\
\hline Ceftriaxone & 11 (8.9\%) & 19 (5.5\%) & $2(6.4 \%)$ & $7(1.4 \%)$ & 39 \\
\hline Cefoperazone-Sulbactam & $5(4.0 \%)$ & $18(5.2 \%)$ & 0 & $1(0.1 \%)$ & 24 \\
\hline Doripenem & $5(4.0 \%)$ & $23(6.7 \%)$ & 0 & $3(0.62 \%)$ & 31 \\
\hline Imipenem & $5(4.0 \%)$ & $20(5.8 \%)$ & $2(6.4 \%)$ & $93(19.2 \%)$ & 120 \\
\hline Meropenem & $6(4.8 \%)$ & 20 (5.8\%) & 0 & 15 (3.1\%) & 41 \\
\hline \multicolumn{6}{|l|}{ Aminoglycosides group } \\
\hline Amikacin & $9(7.3 \%)$ & $20(5.8 \%)$ & $2(6.4 \%)$ & 75 (15.5\%) & 106 \\
\hline Gentamicin & $11(8.9 \%)$ & $20(5.8 \%)$ & $3(9.6 \%)$ & 75 (15.5\%) & 109 \\
\hline Tobramicin & $10(8.1 \%)$ & 18 (5.2\%) & $1(3.2 \%)$ & 15 (3.1\%) & 44 \\
\hline \multicolumn{6}{|l|}{ Quinolone group } \\
\hline $\begin{array}{l}\text { Levofloxacin } \\
\text { Tetracycline group }\end{array}$ & $6(4.8 \%)$ & 19 (5.5\%) & $1(3.2 \%)$ & $5(1.0 \%)$ & 31 \\
\hline $\begin{array}{r}\text { Doxycycline } \\
\text { Polymyxin group }\end{array}$ & $5(4.0 \%)$ & $18(5.2 \%)$ & 0 & $3(0.62 \%)$ & 26 \\
\hline Polymyxin B & 0 & 0 & 0 & 0 & 0 \\
\hline
\end{tabular}

postoperative patients was the most with MDRO in PICU and ICU (Table 2). Intensive Care Units (ICUs) are often referred to as a center of infections, as treated patients are highly susceptible to infections due to immunocompromised conditions as well as increased risk of infection due to obtaining invasive medical measures such as intravenous infusions, intubation or mechanical ventilation. ${ }^{11}$ This study showed the highest number of MDRO was on the use of 3 or more invasive medical devices in the NICU, PICU, and ICU (Table 2).

The highest incidence rate of MDRO was in patients using one type of antibiotic and who had not received antibiotic therapy compared to those using antibiotic combination (Table 2). One of the most common causes of infection is infection by bacteria, so antibiotic treatment is still the primary choice to treat current infections. Various studies had found that about $40-62 \%$ of antibiotics were used improperly for other diseases that did not require antibiotics. ${ }^{12}$ The limitations of this study were the lack of data supporting MDRO risk factors such as the history of care and history of antibiotic therapy in other hospitals.

\section{CONCLUSION AND SUGGESTION}

Based on the results of this study, the unit with the highest incidence of MDRO in the Dr. Wahidin Sudirohusodo Hospital Makassar was ICU with a group of postoperative patients and using 1 type of antibiotic, and who had not received antibiotic therapy. The researchers suggest further control of the rational use of antibiotics for the prevention and control of MDRO infection by monitoring of antibiotic therapy rationally and prevention and control of MDRO infection in each room in the hospital.

\section{REFERENCES}

1. Brunton LL. Goodman \& Gilman's the pharmacological basis of therapeutics. $12^{\text {th }}$ Ed., New York, McGraw-Hill, 2010; 1477-1478.

2. Infection control \& decontamination assurance group. Multi-drug resistant organism policy. Royal Devon and Exeter, NHS Foundation Trust, 2016; 4. 
3. Sadashiv SO, Kaliwal BB. Resistance in bacteria. Insecticides resistance. InTech, 2016. [cited on June 18, 2017]. Available from: https://www.intechopen.com.

4. Brooks FG, Carroll CK, Butel JS, Morse SA, Mietzner TA. Jawetz, Melnick, Adelberg's medical microbiology. $26^{\text {th }}$ Ed., Section III. Bacteriology. New York, Mc-Graw Hill, 2013; 200.

5. Kumar S. Textbook of microbiology. Section 6 . Bacteriology. New Delhi. Jaypee-Brothers Medical Publishers, Ltd. 2012; 237.

6. Karam G, Chastre J, Wilcox MH, Vincent JL. Antibiotic strategies in the era of multidrug resistance. Critical Care, 2016. [cited on June 18, 2017]. Available from: https://www.criticalcare.com.

7. Winarto. Prevalensi kuman ESBL (Extended Spectrum Beta-Lactamase) dan material darah di RSUP Dr. Kariadi Tahun 2004-2005. Semarang, Media Medika
Indonesia, Fakultas Kedokteran Universitas Diponegoro. 2009; 260-267.

8. Siegel DJ, Rhinehart $E$, Jackson $M$, Chiarello L. Management of multidrug resistant organisms in healthcare settings. Department of Health \& Human Services. USA. CDC. 2006; 4.

9. Dwiprahasto I. Kebijakan untuk meminimalkan risiko terjadinya resistensi bakteri di unit perawatan intensif rumah Sakit. Yogyakarta, Fakultas Kedokteran UGM. JMPK, 2005; 08(04): 177.

10. Kurniawati AFS, Satyabakti P, Arbianti N. Perbedaan risiko Multidrug Resistance Organisms (MDROs) menurut faktor risiko dan kepatuhan hand hygiene. Jurnal Berkala Epidemiologi, 2015; 3(3): 277-289.

11. Brusselaers, Labeau SO, Van de Vyver, Vogelaers. Prevention of ventilator-associated pneumonia with oral antiseptics: A systemic review and meta-analysis. 2011. [cited on June 18, 2017]. Available from: htps://www.ncbi.nlm.nih.gov 